\title{
The influence of prior training on GPs' attitudes to sickness absence certification post-fit note.
}

DOI:

$10.1017 / \mathrm{S} 1463423614000577$

\section{Document Version}

Accepted author manuscript

Link to publication record in Manchester Research Explorer

\section{Citation for published version (APA):}

Money, A., Hann, M., Hussey, L., Turner, S., \& Agius, R. (2015). The influence of prior training on GPs' attitudes to sickness absence certification post-fit note. Primary Health Care Research and Development, 16(5), 528-539. https://doi.org/10.1017/S1463423614000577

\section{Published in:}

Primary Health Care Research and Development

\section{Citing this paper}

Please note that where the full-text provided on Manchester Research Explorer is the Author Accepted Manuscript or Proof version this may differ from the final Published version. If citing, it is advised that you check and use the publisher's definitive version.

\section{General rights}

Copyright and moral rights for the publications made accessible in the Research Explorer are retained by the authors and/or other copyright owners and it is a condition of accessing publications that users recognise and abide by the legal requirements associated with these rights.

\section{Takedown policy}

If you believe that this document breaches copyright please refer to the University of Manchester's Takedown Procedures [http://man.ac.uk/04Y6Bo] or contact uml.scholarlycommunications@manchester.ac.uk providing relevant details, so we can investigate your claim.

\section{OPEN ACCESS}




\section{Primary Health Care Research \& Development The influence of prior training on GPs' attitudes to sickness absence certification post- fit note \\ --Manuscript Draft--}

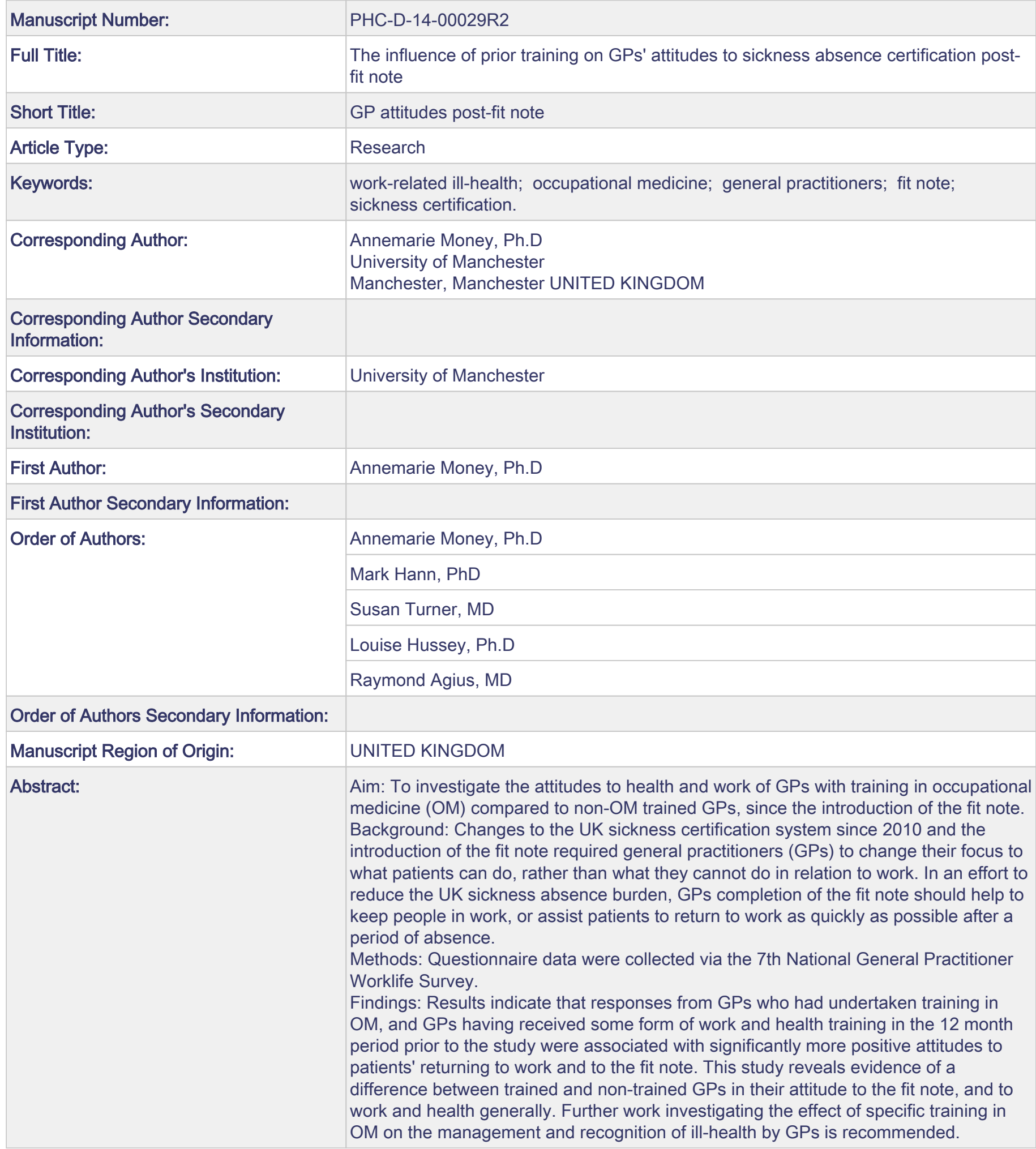




\section{The influence of prior training on GPs' attitudes to sickness absence certification post-fit note}

Dr Annemarie Money, Research Associate, Centre for Occupational and Environmental Health, Centre for Epidemiology, Institute of Population Health, the University of Manchester.

Dr Mark Hann, Research Fellow, Centre for Primary Care, Institute of Population Health, the University of Manchester.

Dr Susan Turner, Senior Clinical Fellow, Centre for Occupational and Environmental Health, Centre for Epidemiology, Institute of Population Health, the University of Manchester.

Dr Louise Hussey, Research Associate, Centre for Occupational and Environmental Health, Centre for Epidemiology, Institute of Population Health, the University of Manchester.

Professor Raymond Agius, Professor of Occupational Medicine, Centre for Occupational and Environmental Health, Centre for Epidemiology, Institute of Population Health, the University of Manchester. 
Click here to download Manuscript (anonymous): GPs attitudes post fit note R2 blinded.doc

The influence of prior training on GPs' attitudes to sickness absence certification post-fit note 
Aim: To investigate the attitudes to health and work of GPs with training in occupational medicine (OM) compared to non-OM trained GPs, since the introduction of the fit note.

Background: Changes to the UK sickness certification system since 2010 and the introduction of the fit note required general practitioners (GPs) to change their focus to what patients can do, rather than what they cannot do in relation to work. In an effort to reduce the UK sickness absence burden, GPs completion of the fit note should help to keep people in work, or assist patients to return to work as quickly as possible after a period of absence.

Methods: Questionnaire data were collected via the $7^{\text {th }}$ National General Practitioner Worklife Survey.

Findings: Results indicate that responses from GPs who had undertaken training in OM, and GPs having received some form of work and health training in the 12 month period prior to the study were associated with significantly more positive attitudes to patients' returning to work and to the fit note. This study reveals evidence of a difference between trained and non-trained GPs in their attitude to the fit note, and to work and health generally. Further work investigating the effect of specific training in $\mathrm{OM}$ on the management and recognition of ill-health by GPs is recommended.

Keywords: work-related ill-health; occupational medicine; general practitioners; fit note; sickness certification. 


\section{Introduction}

Research has shown that worklessness is bad for health, both at the individual and socioeconomic level. Moreover, remaining in, or a quick return to work after a period of sickness absence has many positive benefits [Waddell \& Burton 2006; Black, 2008, Black \& Frost, 2011]. Data from the UK Health and Safety Executive showed that in 2010/11, around 1.1 million people were suffering from ill-health that was caused, or made worse, by their occupation. In addition, around 27 million working days were lost as a result of workrelated ill-health (WRIH) or injury, at an estimated cost to the UK economy of $£ 13.4$ billion [Health \& Safety Executive 2011/12].

It has also been widely recognised that general practitioners (GPs) may struggle with their contractually obliged role in the sickness certification system. Citing a lack of WRIH training, and a concern to maintain the doctor-patient relationship, GPs may feel ill-equipped to offer advice to patients about return to work issues [Hiscock \& Ritchie 2001; Hussey et al, 2004; Wynne-Jones \& Mallen 2009; Money et al, 2010]. This may be unsurprising as only an estimated $4 \%$ of GPs have undertaken specialised postgraduate training in occupational medicine (OM) [Howie 2005; Health and Social Care Information Centre 2009].

In an effort to reduce the burden of sickness absence in the UK, recent Government initiatives have included the introduction of a Statement of Fitness for Work, or fit note, in April 2010 [Department for Work and Pensions, 2010]. Instead of declaring a person to be simply fit or unfit for work, the fit note allows GPs to indicate that a person may be fit for some types of work, and to suggest approaches to facilitate a return to work including a graded return, altered work hours, amended duties and workplace adaptations. The fit note has attempted to shift focus to what a person can do, in terms of the clinical condition and its effect on function, and consequent fitness for work.

Initial fit note evaluations are mixed. From the GPs' perspective evaluations are largely positive [Welsh et al, 2012; Chenery, 2013; Shiels et al, 2013]. However the reaction from industry and employers is less so [Thomson et al, 2012; EEF 2011, 2013]. A fundamental change to the well-established certification system might produce difficulties for GPs who, as reported, can find this aspect of their job both complex and challenging [Tellnes, 1989; Hiscock \& Ritchie 2001; Hussey et al, 2004; Aylward, 2004; Wynne-Jones \& Mallen 2009; Roope et al, 2009; Money et al, 2010]. Given that the focus of the fit note is now very much on what a person can do, it is essential that GPs (via appropriate training) have an understanding of patients' work tasks, and how their day-to-day employment might cause or aggravate ill-health [Coole et al, 2013]. GPs need to be able to make recommendations about the best way to manage a condition while keeping the patient in work, or for getting patients back to work as quickly as possible after a period of absence.

To start to address the training issue, workshops were set up by the Department for Work and Pensions (DWP) in order to provide essential training in health and work so that GPs could complete fit notes effectively. However, a national survey in 2012 found that only a small proportion of GPs (1 in 10 in England and 2 in 10 in Scotland and Wales) had received any WRIH training in the previous 12 month period [Hann \& Sibbald 2013]. The effects of 
training GPs in occupational medicine (OM) on their attitudes and capacity to provide work adjustment advice are unknown. Given the focus on return to work issues and keeping patients in work, there is a presumption that GPs trained in OM might behave differently (i.e. more positively) to GPs without OM training. Therefore, the broad aim of the study reported in this paper is to determine whether GPs with training in OM have different perceptions and attitudes regarding the fit note, compared to non-OM trained GPs.

\section{Method}

The Centre for Primary Care at the University of Manchester was commissioned by the DWP to establish a baseline measure of GPs' knowledge, attitudes and behaviour towards health and work in GB in 2010, against which future work could be benchmarked [Hann \& Sibbald 2011]. Questions relating to GPs' views on work and health; their role, training and confidence in promoting the health benefits of work; early experience of fit notes; and the availability of back to work services, were included in the $6^{\text {th }}$ National General Practitioner Worklife Survey. Thirty questions were developed via a number of strategies. These included a review of policy documents and published research; discussion with policy customers in the Health Work and Well-Being Strategy Unit (HWWB) and also with DWP officials. These questions were subsequently tested via GP focus group and cognitive testing of candidate items in a number of GP interviews. Results were discussed with the HWWB and the questions refined or discarded as appropriate. This resulted in the development of the final 19 questions for use in the survey (See Hann and Sibbald 2011 for a fuller overview).

Questions 1-18 were organised into themes - see Table 1 - and GPs were asked to indicate their answer by ticking 1 of 4 options - completely disagree/somewhat disagree/somewhat agree/completely agree. For the majority of questions, it was anticipated that GPs would agree with the statement: only for questions 6, 7, 15 and 16 was there an 'expectation' that GPs would disagree with the statement. The phrase 'favourable response' is used to describe the anticipated opinions in this paper. For questions $17 \& 18$ an additional (fifth) option was added, i.e. a 'don't know' response. Question 19 required a simple yes/no response about health and work training in the previous 12 months.

<<table 1 here»>

In 2012, the $7^{\text {th }}$ National GP Worklife Survey [Hann \& Sibbald 2012], included a cross sectional element incorporated into the original survey design, which allowed comparison between GPs with prior training in OM and non-OM trained GPs. GPs with training had been trained to Diploma level in Occupational Medicine of the Faculty of Occupational Medicine (DOccMed) and were reporters to The Health and Occupation Research network in General Practice (THOR-GP), a project which aims to determine the incidence of occupational disease and sickness absence burden in the UK [Hussey et al, 2008].

The $7^{\text {th }}$ National GP Worklife Survey was posted to a random selection of 4179 GPs; 2,995 were drawn from the NHS Prescription Services dataset for England, 750 from the NHS Shared Services Partnership dataset for Wales, and 434 Scottish GPs were drawn from the Information Services Division dataset. This sample covers approximately $10 \%$ of all GPs 
from England, Scotland and Wales. To this sample, an additional 182 THOR-GP reporters who had not been selected as part of the 'main' sample - were added, giving a total of 4361 . Questionnaire packs (covering letter, survey questionnaire and pre-paid return envelope) were sent between September and November 2012. Non-responders were mailed up to twice more at 3 weeks intervals. Confidentiality was maintained by identifying GPs using a unique serial number known only to the research team. Ethical approval was given by the North West Multi-centre Research Ethics Committee (MREC 11/NW/0832).

\section{Analysis of Survey Responses}

Survey responses were analysed using Stata [StataCorp 2011]. The representativeness of the respondents was assessed and probability weights (see below) were subsequently derived. The weighted 'raw' data were then summarised for each of the 19 questions, for THOR-GPs and non-THOR GPs separately.

The analysis was undertaken on three GP groups: 1) GPs trained to Diploma level in OM THOR-GPs $(n=107)$. Around $10 \%$ of the non-THOR-GPs stated that they had undertaken some form of training in work and health (but of undefined duration, i.e. a GP road show or equivalent) in the previous 12 months (i.e. answered 'yes' to Q19), therefore the non-THORGPs became 2 further groups, 2) those GPs who had undertaken some work and health training, ( $n=173)$ and 3) GPs with no work and health training $(n=1,483)$.

GPs' responding to the 'completely disagree' and/or 'completely agree' options were few in number (for Qs1-10 the response to either end of the spectrum was less than 5\%; for Qs1116 , the response was less than $10 \%$ ) therefore the 4 response categories were collapsed into 2 , i.e. agree/disagree, for analytical purposes. Binary logistic regression was used to determine whether there were significant differences in responses between the three groups, adjusting for age-group, gender, contract type (GP provider vs. other contract) and country. Odds ratios (OR) and their $95 \%$ confidence intervals (95\% C.I.) are presented to illustrate the strength of these associations.

\section{Results}

Excluding duplicated GPs and undelivered questionnaires (less than $1.5 \%$ of mailout), the overall response rate to this $7^{\text {th }}$ National survey was $40.4 \%$ (40.2\% England; $40.4 \%$ Wales; $41.5 \%$ Scotland). The response rate of the THOR-GP group was $48.6 \%$ ( $48.3 \%$ England; $38.0 \%$ Wales; $60.0 \%$ Scotland).

In general, the greatest response biases within the national random samples were the same across all three countries. There was an over-representation amongst GPs aged 50 to 59 years, and a corresponding under-representation of the youngest (under 35 years), and oldest GPs (60 years and over). In England and Wales, GPs with non-provider contracts were under-represented. Additionally, female GPs were under-represented in Wales.

Within the THOR-GP sample, female GPs were under-represented across all three countries. Moreover, nearly half the THOR-GPs (47\%) are employed in training practices, with larger 
than average practice list numbers. In order to mitigate these biases, and to ensure that the respondent sample more closely reflected the population it was designed to represent, we derived country-specific 'probability' weights for the national data, and THOR-specific weights for the THOR-GPs (all countries combined). These weights were the inverse of the probability of being sampled (not applicable for the THOR sample, as all THOR-GPs were surveyed) - by age-group, gender and contract-type - in each country, adjusted for nonresponse.

\section{Analysis of weighted raw responses}

Table 2 shows that the overwhelming majority of GPs agreed that work was beneficial for health (Q1: 98.6\%) and that worklessness was detrimental to people's health (Q2: 93.0\%). The majority of GPs also agreed that helping patients to stay in or return to work was an important part of a GP's role (Q3: 89.6\%) and an indicator of success in the clinical management of working age patients (Q4: 75.9\%). Around two-thirds of GPs agreed that they had a responsibility to facilitate a patient's return to work (Q5: 66.6\%). Most GPs disagreed that patients had to be fully recovered from their condition before they recommended a return to work (Q6: only 19.9 agreed). However, over three quarters of GPs agreed that they felt obliged to issue sickness certificates for reasons not strictly medical (Q7: 78.3\%). The majority of GPs agreed that they felt confident in dealing with 'return to work' issues (Q8: 62.1\%). Self-reported current knowledge of sickness certification was good (Q9: 80.8\%), but current knowledge of the benefits system was poor (Q10: $27.8 \%$ ). The majority of GPs reported positive impacts of the fit note on the quality of consultations (Q11: 65.6\%, Q12: 64.1\%) and on the outcomes for patients of fit note consultations in their making a return to work (Q13: 60.1\%, Q14: 84.5\%). GPs were roughly evenly split about whether fit notes had lengthened consultation times or not (Q15: 52.1\%): while only a minority reported that it had made no change to their practice (Q16: $28.9 \%$ ). Only a small proportion of GPs perceived that good services were available locally where they could refer patients for advice (Q17: 19.2\%) or support (Q18: 18.0\%).

THOR-GPs were generally most likely to give the favourable response, i.e. to agree to (Qs 15, 8-10) or disagree with (Qs 6-7) questions relating to 'relationships between work and health', a 'GPs role in helping return patients to work', 'return to work management' and 'knowledge of the certification system'. Absolute differences between THOR GPs/trained non-THOR GPs and non-OM trained GPs, in excess of $10 \%$ (which could be viewed as clinically significant, but this is simply a threshold chosen by the authors, it could equally be set at 5\%,15\%,20\%) were observed in response to questions 8,9 and 10 . Moreover, in response to question 8 , THOR GPs and trained non-THORs also differed by more than $10 \%$. This was also the case for question 6 . However, on questions relating to the 'impact of the fit note' and 'service support availability', GPs with some training in work and health gave the favourable response more frequently to Qs 11-16. Collectively, their opinions of the fit note were very similar to THOR-GPs. The responses of other GPs (with some training in OM) to questions 11,13 and 15 differed by more than 10 absolute percentage points compared to non-OM trained GPs. In fact, overall, the responses of GPs with no training appeared to be notably different from the other two groups. We have tested these differences formally, controlling for GP characteristics. The results by 'theme' are discussed in more detail below. $<<$ table 2 here $>$ 


\section{Logistic Regression Analyses}

The regression modelling used 'degree of training' as the key independent variable. Of note, we have only reported odds ratios for significance at the $5 \%$ level. Other pairwise, betweengroup comparisons can, therefore, be assumed to be non-significant at this level.

\section{Relationship between work and health (Q1-2)}

Given that nearly all (98.6\%) of the GPs in the study agreed with the statement 'work is generally beneficial for people's health', we did not conduct a regression analysis on the responses to this question, as there was insufficient variation. There was a statistically significant difference $[O R=2.74 ; 95 \%$ C.I. $=(1.25,6.01) ; p=0.012]$ between THOR-GPs and GPs with no-OM training in response to the statement 'worklessness is generally detrimental to people's health', with the former group being more likely to agree with the statement. However, as very few GPs disagreed with this statement, the findings should be viewed with caution.

\section{GPs role in helping return patients to work (Q3-5)}

There was a statistically significant difference between THOR-GPs and GPs with some training $[\mathrm{OR}=2.84 ; 95 \% \mathrm{C} . \mathrm{I} .=(1.17,6.86) ; \mathrm{p}=0.021]$ and between THOR-GPs and GPs with no-OM training $[O R=3.07 ; 95 \%$ C.I. $=(1.50,6.31) ; p=0.002]$ in their agreement with the statement 'helping patients to stay in or return to work is an important part of a GP's role': THOR-GPs were more likely to agree than either of the other GP groups. THOR-GPs were also more likely to agree with the statement 'staying in or returning to work is an important indicator of success in the clinical management of people of working age', compared with GPs with no-OM training [OR $=1.71 ; 95 \%$ C.I. $=(1.11,2.65) ; p=0.016]$. For the statement, 'GPs have a responsibility to society to facilitate return to work', there was a significant difference between GPs with no-OM training and THOR-GPs [OR $=1.62 ; 95 \%$ C.I. $=(1.06$, 2.46); $p=0.026]$, and a difference between GPs with some training and GPs with no-OM training $[O R=1.42 ; 95 \%$ C.I. $=(0.99,2.03) ; p=0.056]$ : the two GP groups with training were more likely to agree with the statement.

\section{Return to work management (Q6-8)}

THOR-GPs were significantly more likely to disagree with the statements that 'patients had to be fully recovered before recommending a return to work' $[\mathrm{OR}=1.87 ; 95 \%$ C.I. $=(1.12$, 3.14); $p=0.017$ ) and that GPs 'felt obliged to give sickness certificates for reasons that are not strictly medical' $[O R=1.68 ; 95 \%$ C.I. $=(1.10,2.57) ; p=0.017$ ] than GPs with no-OM training. In terms of GPs' confidence in dealing with return to work issues, THOR-GPs [OR = $2.85 ; 95 \%$ C.I. $=(1.76,4.62) ; \mathrm{p}<0.001]$ and GPs with some training $[\mathrm{OR}=1.70 ; 95 \%$ C.I. $=$ $(1.17,2.48) ; p=0.005]$ were significantly more likely to agree with the statement than GPs with no-OM training. 
THOR-GPs [OR for Q9 $=4.24 ; 95 \%$ C.I. $=(2.33,7.73)$ : OR for $\mathrm{Q} 10=2.21 ; 95 \%$ C.I. $=1.55,3.15)$ ] and GPs with some training in work and health [OR for Q9 $=3.22 ; 95 \%$ C.I. $=(1.79,5.82)$ : OR for $\mathrm{Q} 10=2.68 ; 95 \%$ C.I. $=(1.91,3.74)]$ were significantly more likely to agree with both statements than GPs with no-OM training ( $p<0.001$ for all pairwise comparisons). There were no significant differences between THOR-GPs and GPs with some training.

Impact of fit note (Q11-16)

Overall, GPs' responses to the fit note statements were positive and are summarised in Table 3. THOR-GPs and GPs with some training were significantly more likely to agree that the fit note had improved the quality of their discussions with patients (Q11) and advice given (Q12), and increased the frequency with which they recommended a return to work (Q13) than GPs with no-OM training. There were no significant differences between THORGPs and GPs with some training. GPs with some training were statistically significantly less likely to disagree that the fit note had increased consultation length than GPs with no-OM training (Q15).

\section{$<<$ table 3 here >}

\section{Support service availability}

Few GPs agreed with both statements regarding good local services to which they could refer patients for 'advice' and 'support' in returning to work. GPs with some training were more likely to agree to both statements than GPs with no-OM training [OR for Q17 $=2.25$; $95 \%$ C.I. $=(1.56,3.25):$ OR for Q18 $=2.28 ; 95 \%$ C.I. $=(1.57,3.30): p<0.001$ in both cases $]$ and with THOR-GPs [Q18 only: OR $=1.84 ; 95 \%$ C.I. $=(1.07,3.14) ; p=0.026]$.

\section{Aggregated response analysis}

Primarily, we have focussed on GPs' responses to individual questions. However, we were also interested in their 'aggregated' responses within themes (excluding support service availability). The mean scores and the percentage of GPs who gave the favoured response to all questions within the theme - including by 'degree of training' - are shown in Table 4. For the themes 'Relationship between work and health', 'GPs' role in helping patients return to work' and 'Return to work management' the mean scores and percentages of GPs giving all favourable responses increased with increasing OM training. However, this was not the case for the themes 'Knowledge of certification system' and 'Impact of fit note', where the most favourable responses were seen in GPs with some training in OM. Arguably of most interest was the 'Impact of the fit note' theme, where only 1 in 6 GPs gave the favoured response to all 6 questions. This figure varied very little between GPs with different levels of training. On average, overall, GPs gave the favoured response to 4 out of the 6 questions. 
The vast majority of GPs (>90\%) gave the favoured response to both questions enquiring about 'relationships between work and health', whilst just over half (56\%) did so for the three questions on 'GPs' roles in helping return patients to work'. GPs with some training were more likely to give the favoured response to all three questions in this theme. Only 1 in 7 GPs gave the favoured response to all three questions about 'return to work management': this was likely to have been predominantly influenced by responses to question 7, on which the majority of GPs agreed they issued sickness certificates for reasons not strictly medical. Only 2 in 7 GPs gave the favoured response to both questions relating to 'knowledge of the certification system': this can be attributed to poor knowledge of the benefits system (question 10). Again, GPs with some training were more likely to give favourable responses to both questions on this theme.

\section{Discussion}

The underlying hypothesis of the study is that GPs with training in OM, when compared to a randomly selected sample of GPs, will have a more positive attitude towards the fit note. The analyses undertaken show that after controlling for age-group, gender and contract status, THOR-GPs and GPs with some training were, in general, the groups of GPs most likely to indicate the favoured response with more positive attitudes to return to work and fit note issues than GPs with no-OM training. Research undertaken prior to the introduction of the fit note with GPs in THOR had shown that many of these GPs felt that their training was indeed helpful when it came to certifying absence [Money et al, 2010]. Work in Scandinavia has also shown that GPs with postgraduate training in occupational health tend to issue fewer sickness certificates, and those GPs who also worked as part-time industry medical officers, certified shorter periods of absence [Tellnes 1989]. The study reported here found that female GPs and older GPs (aged 55+) consistently indicated the favoured response more often than male GPs and younger GPs. Previous work has found that a GP's gender and age are likely to have an impact on doctor-patient consultations and outcomes, in particular an increased prevalence of male GPs certifying 'intermediate' (6-28 week) sickness absence for male patients [Shiels and Gabbay 2006].

GPs who had undertaken some training in work and health in the previous 12 months were more likely to agree, than GPs with no-OM training, that the introduction of the fit note had increased their consultation times, and that there were good services locally to refer patients for return to work advice and support. These findings may be a result of the recent training in work and health issues that the GPs reported to have received. Training GPs to understand patients' work roles and how adjustments may help keep that person in work, or return to work after sickness absence provides a challenge, but as reaction from employers has shown, this is crucial for realising the potential of the fit note system [EEF 2011, 2013]. Some evidence indicates however, that fit notes are failing to return employees back to work early, and crucially, the fit note advice received by employers from GPs has yet to improve [Coole et al, 2013; CBI report 2013]. Indeed although revised guidance for GPs means they no longer have to give fit note advice specific to the individuals' job, rather the patients' general fitness for work [DWP 2013], some employers feel that GPs continue to lack effective training to fully engage with the fit note process [EEF 2013]. One evaluation of 58,700 fit notes issued between 2011 and 2013 found that in $7 \%$ 
of cases, the GP had not provided any additional advice for the employer and/or patient [Shiels et al 2013]. A recent CBI report [2013] found that only $10 \%$ of employers were confident that GPs were sufficiently trained to use fit notes differently to sick notes, and only $5 \%$ believed GPs to have a sufficient understanding of the workplace to be able to use fit notes to employers' potential benefit. In addition, over two thirds (68\%) of the employers surveyed stated that they were not confident in the training GPs had received for the fit note system.

THOR-GPs and GPs with some training were significantly more likely to agree that they have a responsibility to society to facilitate return to work. The pressure to certify sickness absence within the traditional doctor-patient relationship has long been acknowledged as a barrier in the sickness certification system, with GPs prioritising their role as patients' advocate above their role as gatekeeper [Hiscock \& Ritchie 2001; Hussey et al, 2004; Wynne-Jones \& Mallen 2009; Money et al, 2010]. It is interesting to note that THOR-GPs were more likely than the other two GP groups to disagree with the statement that there was an obligation to give sickness certificates for non-medical reasons. Money et al (2010) found that many GPs trained in OM expressed resistance to the 'traditional' doctor-patient relationship and stated that their training in $\mathrm{OM}$ helped them during sickness absence negotiations with patients, and often facilitated a proactive approach to certification via the inclusion of employers and occupational health services. The wider recognition of the potential impact of the doctor-patient relationship has been addressed through the DWP and Department for Health (DH) funded Fit for Work Service (FFWS) pilot schemes (which were one of the recommendations put forward in the review of the working age population [Black 2008]). Some of the evaluations [AHPF 2013, Thomson et al, 2012; LeicesterFit4Work 2012, Hillage, 2012] identified the importance of using an 'impartial' GP (i.e. not the patients' advocate) for undertaking fit for work consultations and signing of fit notes. It is believed the use of an impartial, occupationally trained GP/other health professional to offer advice could help improve the management of patients at risk of having long term absence from work. Following this pilot work, and in response to the difficulties some GPs appear to have completing fit notes, the DWP is implementing (late 2014) an independent Fit for Work service. This service will be made available (via referral) to patients entering, or expected to enter, 4 weeks of sickness absence. The patient will undergo an assessment by an occupational health professional who will explore the issues preventing a return to work. A plan will be drawn up outlining actions and recommendations for a return to work, and this will, in effect, replace the employers' need for a fit note from the GP with respect to evidence for Statutory Sick Pay [DWP 2014]. The Fit for Work scheme may end up alleviating some of the 'return to work' burden that GPs face, however, GPs will still require an understanding of the issues surrounding health and work in order to recognise and deal with absences of 1-4 weeks which may require adjustments, phased returns, meetings with management/occupational health and so on but which will not be referred to the scheme

\section{Strengths and weaknesses}

The study originally had two main objectives: to investigate whether GPs with training in OM have different perceptions and attitudes regarding the fit note, compared to non-OM trained GPs (as reported here) and secondly, to investigate whether GPs with training in OM 
may differ from other GPs in their management of patients with health and work problems. This second objective was to be explored in a parallel project which aimed to determine the recognition of ill-health caused or aggravated by work in GPs without OM training. However, we were hampered by an extremely low response rate: out of 1975 randomly selected GPs (from the main Worklife sample) presumed not to have OM training, only 15 (1\%) agreed to participate, therefore further research to fulfil this second objective was not pursued. This lack of engagement from GPs is not uncommon in primary care research [Rannard et al, 2013, Hillage, 2012], particularly with respect to long-term worklessness, sickness absence certification and rehabilitation issues. Rannard et al note that, in their experience, workplace health appears to be an area of practice in which GPs report a lack of knowledge, confidence and training, and therefore tend to avoid research precisely because of the challenging issues associated with these areas.

It could be argued that a weakness of the study was the response rate to the first objective (non-OM trained GPs 40\%; THOR-GPs 49\%). However, this is much improved when compared to the response to the $6^{\text {th }}$ National GP Worklife Survey in 2010 (34\%) and is in keeping with the response rates to the first five National GP Worklife Surveys (response rate range of 40-50\%) [Hann and Sibbald, 2011].

The GPs in the National GP Worklife Survey were selected from nationally representative samples and the response biases observed, particularly in terms of an under-representation of younger GPs and female GPs' were corrected and adjusted via 'probability' weights to ensure the sample more closely reflected the population it was designed to represent. The geographical profile of the group of THOR-GPs taking part is also highly comparable to the coverage of GP practices in the UK with preliminary analysis of the population captured by THOR-GP showing it to be nationally representative [Hussey et al 2008]

The eligibility criteria for GPs reporting to THOR-GP is that they are trained to Diploma level in OM (DipOccMed), and as noted, it is estimated that only around 4\% GPs have undergone this specialist training [Howie 2005; Health and Social Care Information Centre 2009]. It could be argued, therefore, that these GPs (given their training) already function to a higher standard in terms of having an appreciation of the issues surrounding health and work, notably rehabilitation back to work and corresponding workplace adjustments. Therefore, a more favourable perspective amongst these GPs might have been expected?

GPs still had limited awareness of local services to which they could refer their patients for advice and/or support about a return to work, which is an area of potential concern. It is unclear though whether GPs thought that such services did not exist in their local area or that they were simply unaware of them. This would depend on the GPs' local knowledge and/or experience, neither of which we have an indication of in this context. It is, therefore, possible that respondents indicated that they disagreed rather than they did not know. Nevertheless, our findings indicate that the responses from GPs who have undertaken training to Diploma level in OM, and GPs who had received some form of work and health training in the previous 12 months (the nature and length of which is unknown), are associated with significantly more positive attitudes to the fit note and a GPs role in helping patients return to work. Significance needs to be considered in the context of absolute 
differences: many of the differences between groups - in percentages in agreement with the statements - are small in absolute terms. Their statistical significance is due to the large sample sizes. Some differences might be significant purely by chance; one would expect 1 in 20 tests to be so. That said, the THOR-GP group and the GP group with some training in health and work do appear more supportive and knowledgeable about patients' health, work and well-being. This study reveals a difference between trained and non-OM trained GPs in their attitudes to the fit note and to work and health generally; a further study to evaluate the effect of $\mathrm{OM}$ on the recognition and management of ill-health is recommended.

Acknowledgements: The National General Practitioners Worklife Survey was funded by the Department of Health Policy Research Programme. The Health and Wellbeing Directorate at the Department for Work and Pensions funded the questions in the survey relating to GPs' attitudes to work and health. This project (no: 138) was funded by the National Institute for Health Research (NIHR) School for Primary Care Research (SPCR). THOR-GP is part of The Health and Occupation Research (THOR) network and programme of research, and is partly funded by the Health and Safety Executive (HSE).

Disclaimer: This article/paper/report presents independent research funded by the National Institute for Health Research (NIHR). The views expressed are those of the author(s) and not necessarily those of the NHS, the NIHR or the Department of Health.

Conflict of interest: None

\section{References}

Allied Health Professions Federation, AHPF, 2013

http://www.ahpf.org.uk/files/AHP\%20Advisory\%20Fitness\%20for\%20Work\%20Report\%20FAQs\%20 Final\%2028-2-13.pdf Last accessed Nov 2013

Aylward, M. 2004. Sickness Certification System in the United Kingdom: Department for Work and Pensions is trying to address challenges. BMJ; 328, 461-462.

Black, C, 2008, Working for a healthier tomorrow - Dame Carol Black's review of the health of the Working age population. London: TSO, 2008

Black, C, and Frost, D. (2011). Health at work - an independent review of sickness absence. TSO. Available at: http://www.dwp.gov.uk/docs/health-at-work.pdf Last accessed March 2014 Chenery, V. 2013. An Evaluation of the Statement of Fitness for Work (fit note): a survey of employees. Department for Work and Pensions (DWP) Research Summary 840

Confederation of British Industry (CBI) 2013, Fit for purpose: absence and workplace health survey, London. http://www.cbi.org.uk/media/2150120/cbi-pfizer absence workplace health 2013.pdf Last accessed March 2014

Coole, C, Watson, PJ, Thomson, L. (2013) How do GPs complete fit note comments? Occup Med, 63(8):575-8

Department for Work and Pensions, 2010 Statement of Fitness for Work, 
http://www.dwp.gov.uk/healthcare-professional/news/statement-of-fitness-for-work.shtml

Last accessed February 2014

Department for Work and Pensions, Health and Well-being Directorate, 2013. Fitness for work: the Governments' response to 'Health at Work: an independent review of sickness absence'. (TSO) London, 2013.

Department for Work and Pensions, 2013. Getting the most out of the fit note: GP guidance https://www.gov.uk/government/uploads/system/uploads/attachment data/file/298821/fitnotegps-guidance-jan-14.pdf Last accessed July 2014

Department for Work and Pensions, 2014. Fit for Work Service Overview

https://www.gov.uk/government/uploads/system/uploads/attachment data/file/317377/healthan d-work-service-specification.pdf Last accessed July 2014

EEF/Westfield-Health-Survey, 2011,

http://www.eef.org.uk/hseblog/post/Key-findings-from-the-EEF-Westfield-Health-Absence-andRehabilitation-Survey.aspx Last accessed March 2014

EEF/Westfield-Health-Survey, 2013,

http://www.westfieldhealth.com/pdfs/EEF/survey/EEF-Sickness-Absence-Survey-2013.pdf

Last accessed July 2014

Electronic Experiential Learning Audit \& Benchmarking - EELAB,

www.medicine.manchester.ac.uk/oeh/eelab Last accessed March 2014

Hann, M \& Sibbald, B. 2011 General Practitioners' attitudes towards patients' health and work.

Department for Work and Pensions (DWP) Research Report 733,

Hann, M \& Sibbald, B. 2013 General Practitioners' attitudes towards patients' health and work, 2010-12. Department for Work and Pensions (DWP) Research Summary 835,

Health and Social Care Information Centre, 2009. General and personal medical services,

England 1998-2008. Accessed October 2013

http://www.ic.nhs.uk/statistics-and-data-collections/workforce/nhs-staff-numbers/nhs-staff-1998--2008-general-practice

Health and Safety Executive Annual Statistics Report 2011/12

http://www.hse.gov.uk/statistics/overall/hssh1112.pdf Last accessed October 2013

Hillage, J, 2012. Evaluation of the Fit for Work Service pilots: first year report. Department for Work and Pensions research report no: 792

Hiscock, J \& Ritchie, J, 2001. The role of GPs in sickness certification. National Centre for Social Research, Department for Work and Pensions Report No 148. Leeds: Department for Work and Pensions.

Howie, J, 2005, Survey of Bradford GPs on work-related ill-health, Bradford Area

Occupational Health and Safety Forum (BAOHSF). 2005.

Hussey, S, Hoddinott, P, Wilson, P, Dowell, J, Barbour, R. Sickness Certification System in the United Kingdom: qualitative study of views of general practitioners in Scotland. BMJ 2004; 328, 88

Hussey, L, Turner, S, Thorley, K, McNamee, R and Agius, R. Work-related ill-health in general practice, as reported to a UK-wide surveillance scheme, Br Journal Gen Pract, 2008; 58, 637-640 
LeicesterFit4Work; Leicester Fit for Work Service, 2012 http://www.leicester.gov.uk/your-councilservices/jobs-and-careers/leicester-to-work/support-into-employment/leicester-fit-for-work/ Last accessed April 2014

Money, A, Hussey, L, Thorley, K, Turner, S, and Agius, R. (2010) Work-related sickness absence negotiations: GPs' qualitative perspectives, Br Journal Gen Pract, 60(579):721-8

Rannard, A, Gabbay, M, Sen, D, Riley, R and Britt, D (2013) Feasibility trial of GP and case-managed support for workplace sickness absence. Primary Care Research and Development 15(3):252-61

Roope, R, Parker, G and Turner, S. 2009. General Practitioners' use of sickness certificates. Occ Med, 2009; 59:580-585.

Shiels, C, and Gabbay, MB. 2006. The influence of GP and patient gender interaction on the duration of certified sickness absence. Fam Pract;23 246-252

Shiels, C, Hillage, J, Pollard, E and Gabbay, M. 2013. An evaluation of the Statement of Fitness for work (fit note): quantitative survey of fit notes. Department for Work and Pensions (DWP) Research Summary 841

Stata [StataCorp], 2011. Stata: Release 12. Statistical Software. College Station, TX: StataCorp LP. Tellnes, G. 1989. Sickness certification in general practice: a review, Family Practice, 6:.58-65.

Thomson, L, and Hampton, R. 2012. Fit for work? Changing fit note practice among GPs. Br Journ Gen Pract, Feb 2012, pp.147-150

Waddell G, and Burton AK. Is work good for your health and well-being? 2006. London TSO.

Welsh, V, Mallen, C, Wynne-Jones, G and Jinks, C. 2012. Exploration of GPs' views and use of the fit note: a qualitative study in primary care. Br Journal Gen Pract, DOI:10.3399/bjgp12X641483

Wynne-Jones G, Mallen C et al. Sickness certification and the GP: what really happens in practice? Fam Pract 2009; 0, 1-7. 
Table 1 National GP Worklife Survey themes and questions

\begin{tabular}{|c|c|}
\hline Theme & Questions \\
\hline $\begin{array}{l}\text { Relationship between work and } \\
\text { health }\end{array}$ & $\begin{array}{l}\text { Q1 Work is generally beneficial for people's health? } \\
\text { Q2 Worklessness is generally detrimental to people's health? }\end{array}$ \\
\hline $\begin{array}{l}\text { GPs' role in helping return patients } \\
\text { to work }\end{array}$ & $\begin{array}{l}\text { Q3 Helping patients to stay in or return to work is an important } \\
\text { part of a GPs' role? } \\
\text { Q4 Staying in or returning to work is an important indicator of } \\
\text { success in the clinical management of people of working age? } \\
\text { Q5 GPs have a responsibility to society to facilitate a return to } \\
\text { work? }\end{array}$ \\
\hline Return to work management & $\begin{array}{l}\text { Q6 A patient has to have recovered fully from their condition } \\
\text { before I recommend a return to work? } \\
\text { Q7 I feel obliged to give sickness certificates for reasons that } \\
\text { are not strictly medical? } \\
\text { Q8 I feel confident in dealing with patient issues around a } \\
\text { return to work? }\end{array}$ \\
\hline Knowledge of certification system & $\begin{array}{l}\text { Q9 My knowledge of guidelines on sickness certification is up- } \\
\text { to-date? } \\
\text { Q10 My knowledge of the benefits system is up-to-date? }\end{array}$ \\
\hline Impa & $\begin{array}{l}\text { Q11 The fit note has improved the quality of my discussions } \\
\text { with patients about a return to work? } \\
\text { Q12 The fit note has improved the advice I give to patients } \\
\text { about their fitness for work? } \\
\text { Q13 The fit note has increased the frequency with which I } \\
\text { recommend a return to work as an aid to patient recovery? } \\
\text { Q14 The fit note has helped my patients make a phased return } \\
\text { to work? } \\
\text { Q15 The fit note has increased the length of my consultations? } \\
\text { Q16 The fit note has made no change to my practice? }\end{array}$ \\
\hline Support service availability & $\begin{array}{l}\text { Q17 There are good services locally to which I can refer } \\
\text { patients for advice about a return to work? } \\
\text { Q18 There are good services locally to which I can refer } \\
\text { patients who need support in returning to work? }\end{array}$ \\
\hline Training in work and health & $\begin{array}{l}\text { Q19 Have you received training in health and work within the } \\
\text { past } 12 \text { months }(\mathrm{Y} / \mathrm{N})\end{array}$ \\
\hline
\end{tabular}


Table 2 Proportion of agreement ${ }^{1}$ with survey questions by all GPs and by GP group

\begin{tabular}{|c|c|c|c|c|}
\hline Question & $\begin{array}{l}\text { GPs with no } \\
\text { training } \\
(n=1,483)\end{array}$ & $\begin{array}{l}\text { GPs with some } \\
\text { training } \\
(n=173)\end{array}$ & $\begin{array}{l}\text { THOR-GPs } \\
(n=107)\end{array}$ & $\begin{array}{c}\text { All } \\
\text { Respondents } \\
(\mathrm{n}=1,763)\end{array}$ \\
\hline $\begin{array}{l}\text { 1. Work is generally beneficial for } \\
\text { people's health? }\end{array}$ & $98.5(1,468)$ & 99.1 (170) & $100.0(104)$ & $98.6(1,742)$ \\
\hline $\begin{array}{l}\text { 2. Worklessness is generally } \\
\text { detrimental to people's health? }\end{array}$ & $92.7(1,464)$ & 94.7 (169) & $96.9(103)$ & $93.0(1,736)$ \\
\hline $\begin{array}{l}\text { 3. Helping patients to stay in or } \\
\text { return to work is an important part of } \\
\text { a GP's role? }\end{array}$ & $89.5(1,468)$ & 90.4 (168) & $96.1(104)$ & $89.6(1,740)$ \\
\hline $\begin{array}{l}\text { 4. Staying in or returning to work is } \\
\text { an important indicator of success in } \\
\text { the clinical management of people of } \\
\text { working age? }\end{array}$ & $75.9(1,463)$ & $75.0(170)$ & $83.8(104)$ & $75.9(1,737)$ \\
\hline $\begin{array}{l}\text { 5. GPs have a responsibility to society } \\
\text { to facilitate a return to work?* }\end{array}$ & $65.7(1,468)$ & $73.6(170)$ & $73.6(103)$ & $66.6(1,741)$ \\
\hline $\begin{array}{l}\text { 6. A patient has to have recovered } \\
\text { fully from their condition before I } \\
\text { recommend a return to work?* }\end{array}$ & $19.5(1,467)$ & $24.4(170)$ & $10.6(104)$ & $19.9(1,741)$ \\
\hline $\begin{array}{l}\text { 7. I feel obliged to give sickness } \\
\text { certificates for reasons that are not } \\
\text { strictly medical? }\end{array}$ & $78.8(1,466)$ & 75.5 (169) & $70.2(104)$ & $78.3(1,739)$ \\
\hline $\begin{array}{l}\text { 8. I feel confident in dealing with } \\
\text { patient issues around a return to } \\
\text { work? }\end{array}$ & $60.7(1,465)$ & $71.9(170)$ & $82.1(104)$ & $62.1(1,739)$ \\
\hline $\begin{array}{l}\text { 9. My knowledge of guidelines on } \\
\text { sickness certification is up-to-date? }\end{array}$ & $79.3(1,469)$ & $92.5(170)$ & $94.3(104)$ & $80.8(1,743)$ \\
\hline $\begin{array}{l}\text { 10. My knowledge of the benefits } \\
\text { system is up-to-date? }\end{array}$ & $25.3(1,467)$ & $47.9(170)$ & $40.4(104)$ & $27.8(1,741)$ \\
\hline $\begin{array}{l}\text { 11. The fit note has improved the } \\
\text { quality of my discussions with } \\
\text { patients about a return to work? }\end{array}$ & $64.4(1,470)$ & 74.5 (170) & $74.1(102)$ & $65.6(1,742)$ \\
\hline $\begin{array}{l}\text { 12. The fit note has improved the } \\
\text { advice I give to patients about their } \\
\text { fitness for work? }\end{array}$ & $63.0(1,468)$ & $72.6(170)$ & $71.1(102)$ & $64.1(1,740)$ \\
\hline $\begin{array}{l}\text { 13. The fit note has increased the } \\
\text { frequency with which I recommend a } \\
\text { return to work as an aid to patient } \\
\text { recovery? }\end{array}$ & $58.4(1,465)$ & $73.3(170)$ & $68.3(102)$ & $60.1(1,737)$ \\
\hline $\begin{array}{l}\text { 14. The fit note has helped my } \\
\text { patients make a phased return to } \\
\text { work? }\end{array}$ & $83.9(1,466)$ & $88.7(170)$ & $87.7(101)$ & $84.5(1,737)$ \\
\hline $\begin{array}{l}\text { 15. The fit note has increased the } \\
\text { length of my consultations?* }\end{array}$ & $51.0(1,465)$ & $61.1(169)$ & $58.7(102)$ & $52.1(1,736)$ \\
\hline $\begin{array}{l}\text { 16. The fit note has made no change } \\
\text { to my practice?* }\end{array}$ & $29.6(1,464)$ & $23.3(170)$ & $24.5(103)$ & $28.9(1,737)$ \\
\hline $\begin{array}{l}\text { 17. There are good services locally to } \\
\text { which I can refer patients for advice } \\
\text { about a return to work? }\end{array}$ & $17.5(1,469)$ & 32.4 (169) & $21.8(103)$ & $19.2(1,741)$ \\
\hline $\begin{array}{l}\text { 18. There are good services locally to } \\
\text { which I can refer patients who need }\end{array}$ & $16.4(1,468)$ & $31.3(170)$ & $18.2(103)$ & $18.0(1,741)$ \\
\hline
\end{tabular}

\footnotetext{
${ }^{1}$ Results expressed as percentages relate to proportion of GP groups 'agreeing' with the question whereby agreement is the 'favoured' response unless indicated by a * in which case the 'favoured' response was to disagree.
} 


\begin{tabular}{|l|l|l|l|l|}
\hline support in returning to work? & & & \\
\hline $\begin{array}{l}\text { 19. Have you received training in } \\
\text { health and work within the past } 12 \\
\text { months }(\mathrm{Y} / \mathrm{N})\end{array}$ & $0.0(1,435)$ & $100.0(170)$ & $36.4(102)$ & $11.2(1,707)$ \\
\hline
\end{tabular}

Table 3 Responses to fit note section of Worklife survey

\begin{tabular}{|c|c|c|c|}
\hline Question & $\begin{array}{l}\text { Overall } \\
\text { Response }\end{array}$ & $\begin{array}{l}\text { Omnibus Significance } \\
\text { Test }\end{array}$ & Pairwise Groups that differ \\
\hline $\begin{array}{l}\text { 11. The fit note has improved the } \\
\text { quality of my discussions with } \\
\text { patients about a return to work }\end{array}$ & $66 \%$ agreed & $P=0.001$ & $\begin{array}{l}\text { THOR-GPs \& GPs with no training [OR = 1.77; } \\
95 \% \text { C.I. }=(1.20,2.61) ; p=0.004] \\
\text { GPs with some training \&GPs with no training } \\
\text { [OR = 1.63; } 95 \% \text { C.I. }=(1.11,2.39) ; p=0.012 \text { ] }\end{array}$ \\
\hline $\begin{array}{l}\text { 12. The fit note has improved the } \\
\text { advice I give to patients about their } \\
\text { fitness for work }\end{array}$ & $64 \%$ agreed & $P=0.003$ & $\begin{array}{l}\text { THOR-GPs \& GPs with no training [OR = 1.65; } \\
95 \% \text { C.I. }=(1.14,2.40) ; p=0.008] \\
\text { GPs with some training \&GPs with no training } \\
\text { [OR }=1.57 ; 95 \% \text { C.I. }=(1.08,2.27) ; p=0.017]\end{array}$ \\
\hline $\begin{array}{l}\text { 13. The fit note has increased the } \\
\text { frequency with which I recommend a } \\
\text { return to work as an aid to patient } \\
\text { recovery }\end{array}$ & $60 \%$ agreed & $P<0.001$ & $\begin{array}{l}\text { THOR-GPs \& GPs with no training }[\mathrm{OR}=1.70 ; \\
95 \% \text { C.I. }=(1.18,2.45) ; p=0.004] \\
\text { GPs with some training \&GPs with no training } \\
\text { [OR }=1.95 ; 95 \% \text { C.I. }=(1.35,2.82) ; p<0.001]\end{array}$ \\
\hline $\begin{array}{l}\text { 14. The fit note has helped my } \\
\text { patients make a phased return to } \\
\text { work }\end{array}$ & $85 \%$ agreed & $P=0.128$ & None at $5 \%$ level of significance \\
\hline $\begin{array}{l}\text { 15.The fit note has increased the } \\
\text { length of my consultations }\end{array}$ & $\begin{array}{l}48 \% \\
\text { disagreed }\end{array}$ & $P=0.015$ & $\begin{array}{l}\text { GPs with some training \&GPs with no training } \\
{[O R=1.60 ; 95 \% \text { C.I. }=(1.13,2.25) ; p=0.008]}\end{array}$ \\
\hline $\begin{array}{l}\text { 16. The fit note has made no change } \\
\text { to my practice }\end{array}$ & $\begin{array}{l}71 \% \\
\text { disagreed }\end{array}$ & $P=0.074$ & None at $5 \%$ level of significance \\
\hline
\end{tabular}

Table 4 Mean scores by theme for all GPs and GP groups.

\begin{tabular}{|c|c|c|c|c|c|}
\hline $\begin{array}{c}\text { Theme } \\
\text { (possible range of scores) }\end{array}$ & $\begin{array}{l}\text { Items with 'favoured' } \\
\text { response }\end{array}$ & $\begin{array}{l}\text { GPs with no } \\
\text { training } \\
(n=1,483)\end{array}$ & $\begin{array}{l}\text { GPs with some } \\
\text { training } \\
\quad(n=173)\end{array}$ & $\begin{array}{l}\text { THOR-GPs } \\
(n=107)\end{array}$ & $\begin{array}{c}\text { All } \\
\text { Respondents } \\
(n=1,763)\end{array}$ \\
\hline $\begin{array}{l}\text { Relationship between work } \\
\text { and health }(0-2)\end{array}$ & \multirow{5}{*}{$\begin{array}{l}\text { Mean (Standard Error) of } \\
\text { number of items with } \\
\text { favoured response within } \\
\text { the theme }\end{array}$} & $\begin{array}{l}1.91(0.01) \\
91.5(1,463)\end{array}$ & $\begin{array}{l}1.94(0.02) \\
93.7(169)\end{array}$ & $\begin{array}{l}1.97(0.01) \\
96.9(103)\end{array}$ & $\begin{array}{l}1.92(0.01) \\
91.8(1,735)\end{array}$ \\
\hline $\begin{array}{l}\text { GPs' role in helping return } \\
\text { patients to work (0-3) }\end{array}$ & & $\begin{array}{l}2.31(0.02) \\
55.3(1,460)\end{array}$ & $\begin{array}{l}2.40(0.07) \\
61.5(168)\end{array}$ & $\begin{array}{l}2.53(0.06) \\
68.1(103)\end{array}$ & $\begin{array}{l}2.32(0.02) \\
56.0(1,731)\end{array}$ \\
\hline $\begin{array}{l}\text { Return to work } \\
\text { management (0-3) }\end{array}$ & & $\begin{array}{l}1.63(0.02) \\
14.0(1,458)\end{array}$ & $\begin{array}{l}1.72(0.06) \\
15.1(169)\end{array}$ & $\begin{array}{l}2.01(0.06) \\
21.5(104)\end{array}$ & $\begin{array}{l}1.64(0.02) \\
14.2(1,731)\end{array}$ \\
\hline $\begin{array}{l}\text { Knowledge of certification } \\
\text { system (0-2) }\end{array}$ & & $\begin{array}{l}1.05(0.02) \\
24.5(1,467)\end{array}$ & $\begin{array}{l}1.40(0.05) \\
47.9(170)\end{array}$ & $\begin{array}{l}1.35(0.04) \\
40.0(104)\end{array}$ & $\begin{array}{l}1.09(0.02) \\
27.1(1,741)\end{array}$ \\
\hline Impact of fit note (0-6) & & $\begin{array}{l}3.89(0.05) \\
17.5(1,458)\end{array}$ & $\begin{array}{l}4.26(0.12) \\
19.4(169)\end{array}$ & $\begin{array}{l}4.21(0.13) \\
17.3(101)\end{array}$ & $\begin{array}{l}3.93(0.04) \\
17.7(1,728)\end{array}$ \\
\hline
\end{tabular}

